\title{
Ideological Morality, Generality, and Particularity of Pip and Gatsby in Charles Dickens' Great Expectations and F. Scott Fitzgerald's The Great Gatsby
}

\section{| Shaghayegh Moghari |}

DOI: https://doi.org/10.47175/rissj.v2i1.182

Semnan University, Iran

shaghayeghmoghari@gmail.com

\begin{abstract}
'Subaltern' and 'other' are the two labels that are attributed to the weaker members of the society and the whole world in general sense in terms of color of the skin, the gender, the financial conditions, and the social status. This study attempts hard to defend the characters of Pip and Gatsby who were considered as 'subaltern' and 'other' by the unjust society and system around them and as a result, though they attained the wealth they always dreamed of, they failed to attain a good life that they deserved. Even Pip, who succeeded in marrying his beloved, cannot be regarded as a lucky guy because he was able to have her only after a divorce that she experienced in her first marriage; so, this cannot be taken as a success for Pip. The following issues will be expanded and examined in details to clarify the way the present researcher has always tried to encourage the world around her to treat the weaker better, and also to convert the world into a better place to live by enjoying equal rights for all: Gayatri Spivak, the voice of the voiceless, 'Other' and 'subaltern' in Pip and Gatsby, and the unfair oppression of the world against the so called 'other' and 'subaltern.'

KEYWORDS

Subaltern; Gayatri Spivak; Pip; Gatsby; poverty; social status; the voice of the voiceless; equal rights
\end{abstract}

\section{INTRODUCTION}

This article is a study of the characterizations of Pip and Gatsby in Great Expectations and The Great Gatsby written by Charles Dickens in 1860, and F. Scott Fitzgerald in 1925, respectively. To the present researcher, it has been a life-long-passion to defend the rights of the oppressed, the poor, or in other words the 'subaltern' and 'other' against the oppression and injustice of the world. This article is actually attempting to approach the characters of Pip and Gatsby through the lens of Spivak criticism. These two characters were both poor guys in society and as a result were treated coldly and with contempt merely because of their poor and weak backgrounds. Both of them decided to attain great wealth and social status in order to remove the label of 'subaltern' and 'other' from themselves. When at the beginning of both novels they were poor, they both fell in love with beautiful rich girls who belonged to higher social levels of society. They both were rejected because of their socially weak backgrounds. Both of them worked hard in order to achieve too much money and social status to deserve their beloveds. At the end, Pip was successful in winning the hand of his beloved only after she had failed in her first marriage; and, Gatsby totally failed winning his beloved and was murdered innocently because of that girl's mistake. This article will discuss the Gayatri Spivak who is actually the pioneer of Spivak literary school criticism, the voice of the voiceless, subaltern in Pip 
and Gatsby, and a comparative focus on Pip and Gatsby. In the part of the Conclusion, the present research will condemn the way society treated the poor or the weak as 'other' and 'subaltern' solely because of their backgrounds. Also, it will explore the idea that if those people who are considered as 'other' or 'subaltern' were treated equally in the world, would they experience such bitter end as Pip and Gatsby did? They were considered as inferior to the people around them from higher levels of the society merely because of their poverty and not because of their capabilities. This study does its best to convince the whole readers into having better outlooks of those who are labeled as 'subaltern' and 'other' in order not to experience the bitter outcomes which Pip and Gatsby went through solely because of being labeled as 'other' and 'subaltern' unfairly. Hereby, this article will benefit the ideas and opinions of Gayatri Spivak to be authenticated and capable in changing the unjust view of the world toward the so called subaltern.

\section{RESEARCH METHODS}

There have been many studies on the weaker people of the world and their fair rights throughout especially the last two centuries done mainly through the points of view of Feminism and Post-colonialism. All of them concern defending the rights of the oppressed against the oppressor. The present researcher decided to choose Spivak because that is a more modern field of literary criticism by which this study could attain its goal. The main literary figure that was chosen to strengthen this article among those who approached their literary study through Spivak point of view was Gayatri Spivak, the founder of this approach, who wrote "A literary Representation of the Subaltern: A woman's Text from the Third World.", "Can the Subaltern Speak?", and "The Spivak Reader: Selected works of Gayatri Chakravotry Spivak." In all these three works she tries hard to fight against the contemptuous look with which those in power and wealth dominate the poor and the weak groups as 'other' or 'subaltern.' Also Frantz Fanon, in his The wretched of the earth, tries to express the voice of the weak and subaltern who have been regarded as inferior to those in better conditions, and at the end, he tries to indirectly convince the world into having better points of view towards those in poor conditions. This article is a contribution of Spivak criticism by choosing two novels and focusing on them comparatively from this theoretical stance.

\section{RESULTS AND DISCUSSION}

\section{Gayatri Spivak}

Spivak is a renowned literary figure and a great voice of the post-colonial era since the publication of her essay "Can the Subaltern Speak?" She has commented on Marxism, Feminism and Deconstruction. Spivak, the post-colonial literary figure, was born in India on February 24, 1942. She graduated from Presidency College of the University of Calcutta in 1959 with first-class degree majoring in English. She then went to U. S. A. Then she went to England to earn a fellowship at Girton College, Cambridge. Spivak came back to the U. S. A. after she was done with the fellowship in England for having the job of a professor at Iowa University. At the same time she finished her Ph.D. thesis on the Irish poet W. B. Yeats and the research work was supervised by the literary critic Paul de Man at Cornell University, New York. Currently, she is Avalon Foundation Professor in the Humanities at Columbia University, New York. Her great translation of Jacques Derrida's Of Grammatology brought international fame for Gayatri Chakravorty Spivak. Spivak tried to challenge the influences of colonialism. She rejected to acknowledge the thought that 
the Western World has a better hand over the Third World countries. Her critical thoughts provokes the subjects of marginal issues like the position and stance of the subaltern population especially women in the society and their power. Though the people could conquer the colonial injustices, they are not in fact free from its negative effects and its norms. Morton says:

The social, political and economic structures that were established during colonial rule continued to inflect the cultural, political and economic life of Post-colonial nation states ranging from Ireland to Algeria; from India to Pakistan and Jamaica to Mexico. In common with many anti-colonial intellectuals, including Frantz Fanon (1925-61) and Partha Chatterje (1947 - ), Spivak emphasizes how anti-colonial nationalism assumed a distinctively bourgeois character, and was thus perceived by many to reproduce the social and political inequalities that were prominent under colonial rule (1 - 2).

Spivak coins the word 'subaltern' from Gramsci, to allude to the groups of people in the society (Gramsci 55). In the Indian culture, the word 'subaltern' receives more attention as the people have tried hard to attain Indian independence. She prefers the term 'subaltern' because it has the exact image of the people who belong to lower classes of the society. Morton quotes the words of Spivak as:

I like the word subaltern for one reason. It is totally situational. Subaltern began as a description of a certain rank in the military. The word was under censorship by Gramsci: he called Marxism „monism“e, and was obliged to call the proletarian ,subaltern." That word, used under duress, has been transformed into the description of everything that doesn ${ }^{\text {ee }} t$ fall under strict class analysis. I like that, because it has no theoretical rigor (46).

India is a very big land of various things. It is consisted of different states and parts in terms of religion, class, gender, language, citizenship, and ethnicities. With regard to this tremendous big outlook, the circumstances of the subaltern are all the more pitiable. Spivak became a renowned literary figure by her famous essay "Can the Subaltern Speak?" The essay talks about the conditions of women in India who devote themselves in favor of their families. Spivak offers a theory of subalternity in her essay "Can the Subaltern Speak?" In this essay, she vindicated the limitations of the subalterns, asking "Can the Subaltern Speak?" (283). By 'subaltern' Spivak means the oppressed subjects or more generally those "of inferior rank" (283). She goes on to add that "In the context of colonial production, the subaltern has no history and cannot speak, the subaltern as female is even more deeply in shadow" (287). Spivak concludes the essay "Can the Subaltern Speak?" by reiterating her standpoint that "the subaltern cannot speak" (308). Spivak's notions are in fact a preventive response for all the further questions. It is a result of her life-long pursuing the truth and it is being used with regard to socio-cultural structures. The theory indicates that the subaltern can speak but others do not have any regard for or the patience to listen to them with respect. The message sent by the one who sends it does not reach to the would-be-receiver since it is prevented by the factor of noise. Articulation is a kind of act by the humans but to translate the messages in the actual life requires tremendous attempts on the side of the receivers. Morton makes the wide difference clear between articulation and interpretation of the subaltern women in the following sentences:

Spivak's conclusion that the subaltern cannot speak is often taken out of context to mean that subaltern women have no political agency because they 
cannot be represented. Such a reading is actually contrary to the very situated theoretical framework that Spivak establishes in "Can the Subaltern Speak?" Spivak would certainly not want to deny the social agency and lived existence of disempowered subaltern women. The crucial point, however, is that these disempowered women receive their political and discursive identities within historically determinates systems of political and economic representation (66$67)$.

\section{The Voice of the Voiceless}

In her eminent essay "Can the Subaltern Speak?" Spivak talks about different matters about sati, the custom of widow self-immolation. It was the best example to defend the argument that the subaltern women did not get the chance to think about their own ideas and persuade the society about their different voice. The British people were the rulers of the colonized India and they tried to annul that old ritual of widow sacrifice in 1829. Sati is a Sanskrit word meaning widow and she is considered as a good and dedicated wife for her husband when she goes up to the pyre of her deceased husband and joins her husband in the action of self-immolation. The British people chose the term suttee instead of sati and the annihilation of this evil custom was done by the colonial statesmen as a part of the civilizing operation. The messages from the colonial ruler men were that "white men saving brown women from brown men" (Spivak, 293). But to their utmost dissatisfaction, the British rulers never came to understand that some of the women in India sincerely wanted to be burnt with their dead husbands in the funeral pyre as a supreme deed of selfimmolation. Both Dharmasastra and Rg-Veda, ancient Hindu religious texts, regard the custom of wife self-immolation as a noble ritual for the dead husband, rather than an action of suicide:

The two moments in the Dharmasastra that I am interested in are the discourse on sanctioned suicides and the nature of the rites for the dead. Framed in these two discourses, the self-immolation of widows seems an exception to the rule. The general scriptural doctrine is that suicide is reprehensible. Room is made, however, for certain forms of suicide which, as formulaic performance, lose the phenomenal identity of being suicide (Spivak, Can the Subaltern Speak? 299).

People did the ritual of widow self-immolation because it was allowed in the Dharmasastra. Spivak questions the rationality of this awful human devotion by saying that "this is not the proper place for the woman to annul the proper name of suicide through the destruction of the proper self" (Can the Subaltern Speak? 300). Self-immolation has achieved a divine implication and the service is extremely male-oriented where the domination of patriarchy is thoroughly visible through the devotion of this widow sacrifice. The ritual of sati helped the men to want more respect from women. Women prior to independent India played the part of a parasite. A parasite is a living insect like a woman and it does not have independent existence. While the main tree falls to the ground, the existence and life of the parasite is under severe threat. The tree and the parasite stop existing at the same time. The woman is nothing different from the parasite. The exact moment her husband dies, the woman loses her chance to live as an independent individual and recaptures her individuality with her husband on the funeral pyre.

Spivak is in favor of the point-of-view that because of the religious aura coming from the self-immolation, the custom of widow sacrifice cannot be regarded as a deed of suicide but "a simulacrum of both truth-knowledge and piety of place" (Can the Subaltern Speak? 300). The repudiation of self-sacrifice on the funeral pyre of the dead husband is taken 
with contemptuous look and the society will regard her as a living sample of conjugal ungratefulness:

It is in terms of this profound ideology of the displaced place of the female subject that the paradox of free choice comes into play ... By the inexorable ideological production of the sexed subject such a death can be understood by the female subject as an exceptional signifier of her own desire, exceeding the general rule for a widow's conduct (300).

In "Can the Subaltern Speak?" Spivak says that "Sati should have been read with martyrdom" (302). A martyr does not die for the sake of himself/herself. His/her blood is dropped for the sake of others from which she/he has no personal benefit. The women who were burnt as satis were considered as martyrs. This martyrdom was actually a kind of complaint against the society and its customs, for it actually failed to realize their role in the society together with the members of their families. British colonial manager, Edward Thompson, published his Suttee: A Historical and Philosophical Enquiry in the Hindu Rite of Widow-Burning in 1928. In "Can the Subaltern Speak?", Spivak discusses that Thompson has made the entire situation worse and more complicated by stating that "white men, seeking to save brown women from brown men, impose upon those women a greater ideological constriction by absolutely identifying, within discursive practice, goodwifehood with self-immolation on the husband"s pyre" (305). The British rulers in India tried to stop the repetition of sati in order to rationalize imperialism as a part of their civilizing undertaking:

Such a claim repeats the silencing of the Hindu woman's voice, which is already displaced on to her dead husband's funeral pyre in the traditional Hindu religious codes ... Rather than defending the woman's agency, however, the British colonial administration used the body of the widow as an ideological battleground for colonial power. In doing so the British were able to justify colonialism, or the systematic exploitation and appropriation of territory, as a civilizing mission. In both the Hindu and British discussions of widow sacrifice, the voice and political agency of the woman is thoroughly repressed from official historical discourse and political representation (Morton $63-64)$

In "Can the Subaltern Speak?" Spivak protests vehemently against Edward Thompson's Suttee because of two specific reasons: firstly, "Thompson's using the word sati as "faithful" in the first sentence of the book and the second one is for Thompson's praise for General Charles Hervey's viewpoint on this issue that "brings out the pity of a system which looked only for prettiness and constancy in woman" (305). "Can the subaltern speak?" is a question asked rhetorically by Spivak and her aim was not to have or hear any sort of answer, rather to talk about the obstacles of the subaltern. The article "Can the Subaltern Speak?" talks about the matter of widow sacrifice in full detail and Spivak defends her opinion that subaltern cannot speak and the condition of the women is even far more problematical. Although women obeyed the caprices and desires of their husbands, they had an internal voice in themselves, a voice of dissension and dissatisfaction. All women who were taken as the victims of male-dominated violence and violence had something to express or, at least, they needed to make their position be understood whether they were in favor or against such things. The historian actually failed to make the voice of dissent and especially that of the subaltern women known. Now, it would be actually very challenging to correct the opposing voice of the subaltern and the situation will later be 
more complicated as they were lost between colonial power system and the Hindu religious norms:

The British government put a ban on the custom of sati, but as a result of that several women who could have died a cruel but quick death when husbands died now have to face an agonizing slow death (Tharu, 363).

\section{Pip and Gatsby as the Victims of the Cruel System of their Society}

Both Pip and Gatsby could be regarded as the innocent victims of the unfair system of their societies because they both were competent enough to enjoy a happy life by meeting their wishes. Both of them tried hard to attain what they had aspired for throughout their lives, but none of them could satisfactorily build a future full of joy. In terms of Pip who was actually doing his best since the earliest days of his childhood in order to come up with a good future of both high social status and money to deserve his old love, unfortunately he was not that much lucky to win her hand because he could only have her after she had failed in her first marriage. So, Pip could not be regarded as that much successful in winning her hand when she had not experienced her first marriages. The society in which Pip tried hard to attain a life like that of the rich who were not considered as subaltern or other is to blame here because of considering him as other and not providing him with the same facilities that people from higher levels of the society could enjoy. Likewise, when it comes to Gatsby, he can be regarded as not that much different from Pip because he was a competent great youth belonging to lower levels of the society who had fallen in love with a girl of higher social levels which unfortunately had labeled him as other and subaltern merely due to his poor background. But, unfortunately Gatsby came up with a much harsher result that Pip experienced because he was cruelly killed because of a mistake that was not his own, rather that mistake was his beloved's. Gatsby did all he could to win the hand of his beloved, he achieved great wealth but there was nothing he could do to clean his poor low class background. The society did not let him enjoy the life in proportion to his former efforts and as a result he actually remained that other and subaltern giving his valuable life for a girl who did not deserve all his great manners and efforts. Spivak was chosen in this study to approach these two characters of Pip and Gatsby in order to analyze them as other or subaltern in terms of their weak background and social status.

\section{CONCLUSION}

The application of the findings of this article will be a respected view of those people considered as inferior under the names of 'subaltern' and 'other' only because of their lack of social status or financial conditions. If the society or the whole world, in a general sense, respects the poor or all those who can be regarded as inferior, because of e.g. the color of their skin (racial discrimination and sometimes Post-colonialism), or their gender (Feminism), or specifically discussed in this article because of their being from the lower levels of the society (Spivak), then the world would be a better place to live with equal rights for all without harming the rich or depriving the rich from their former facilities and conditions. So it is a shame to face such bitter results in lives of the characterizations of Pip and Gatsby both in literature and in real life..

\section{REFERENCES}

Dickens, Charles. (2002). Great Expectations. New York: Penguin Classics. Fanon, Frantz. (1990). The Wretched of the Earth. London: Penguin 
Fitzgerald, F. Scott. (1995). The Great Gatsby.1925. New York: Scribner Paperback Fiction,

Spivak, Gayatri Chakravorty. (1987). "A Literary Representation of the Subaltern: A Woman "s Text from the Third World." In Other Worlds: Essays in Cultural Politics. New York: Methuen, $241-268$.

. (1988). "Can the Subaltern Speak?" Marxism and the Interpretation of

Culture. Ed. Cary Nelson and Lawrence Grossberge. London: Macmillan. 271 - 313. (1996). The Spivak Reader: Selected Works of Gayatri Chakravorty Spivak.

Ed. Donna Landry and Gerald Mac Lean. New York: Routledge.

Gramsci, Antonio. (2004). Selections from the Prison Notebooks of Antonio Gramsci.

Trans. and ed. Quintin Hoare and Geoffrey Nowell Smith. (2003). Chennai: Orient Longman.

Morton, Stephen. Gayatri Chakravorty Spivak. (2003). London: Routledge

Tharu, Susie, and K. Lalita, eds. (1992). Women Writing in India: 600 B.C. to the Present. Vol. 1. Delhi: Oxford U P..

Thompson, Edward. (1928). Suttee: A Historical and Philosophical Enquiry in the Hindu Rite of Widow-Burning. London: George Allen and Unwin. 